\title{
Phytotoxin synthesis genes and type III effector genes of Pseudomonas syringae pv. actinidiae biovar 6 are regulated by culture conditions
}

\author{
Karin Hirose $^{1,2}$, Yasuhiro Ishiga ${ }^{2}$, Takashi Fujikawa ${ }^{\text {Corresp. } 1}$ \\ ${ }^{1}$ Institute of Fruit Tree and Tea Science, National Agriculture and Food Research Organization (NARO), Tsukuba, Ibaraki, Japan \\ 2 Faculty of Life and Environmental Science, University of Tsukuba, Tsukuba, Ibaraki, Japan \\ Corresponding Author: Takashi Fujikawa \\ Email address: ftakashi@affrc.go.jp
}

The kiwifruit bacterial canker (Pseudomonas syringae pv. actinidiae; Psa) causes severe damage to kiwifruit production worldwide. Psa biovar 6 (Psa6), which was isolated in Japan in 2015, produces two types of phytotoxins: coronatine and phaseolotoxin. To elucidate the unique virulence of Psa6, we performed transcriptomic analysis of phytotoxin synthesis genes and type III effector genes in in vitro cultivation using various media. The genes related to phytotoxin synthesis and effectors of Psa6 were strictly regulated in the coronatine-inducing mediums (HS and HSC); 14 of 23 effector genes and a hrpL sigma factor gene were induced at $3 \mathrm{~h}$ after transferring to the media (early-inducible genes), and phytotoxin synthesis genes such as argD of phaseolotoxin and $c f l$ of coronatine were induced at 6 and $12 \mathrm{~h}$ after transferring to the media (late-inducible genes). In contrast, induction of these genes was not observed in the hrp-inducing medium. Next, to examine whether the changes in gene expression in different media is specific to Psa6, we investigated gene expression in other related bacteria. For Psa biovar 1 (Psa1), biovar 3 (Psa3), and P. s. pv. glycinea (Psg), no clear trends were observed in expression behavior across various culture media and incubation times. Therefore, Psa6 seems to exert its virulence efficiently by using two phytotoxins and effectors according to environmental changes. This is not seen in other biovars and pathovars, so it is thought that Psa 6 has acquired its own balance of virulence. 
1 Phytotoxin synthesis genes and type III effector genes

2 of Pseudomonas syringae pv. actinidiae biovar 6 are

3 regulated by culture conditions

4

5

6

7

8

9

10

11

12

13

14

15

16

17

18

19

20

21

22

23

24

25

26

27

28

29

30

31

32

33

34

35

36

37

38

Karin Hirose ${ }^{1,2}$, Yasuhiro Ishiga ${ }^{2}$, Takashi Fujikawa ${ }^{1}$

${ }^{1}$ Institute of Fruit Tree and Tea Science, National Agriculture and Food Research Organization (NARO), Tsukuba, Ibaraki, Japan

${ }^{2}$ Faculty of Life and Environmental Science, University of Tsukuba, Tsukuba, Ibaraki, Japan

Corresponding Author:

Takashi Fujikawa

Fujimoto 2-1, Tsukuba, Ibaraki, 305-8605, Japan.

E-mail address: ftakashi@affrc.go.jp

\section{Abstract}

The kiwifruit bacterial canker (Pseudomonas syringae pv. actinidiae; Psa) causes severe damage to kiwifruit production worldwide. Psa biovar 6 (Psa6), which was isolated in Japan in 2015, produces two types of phytotoxins: coronatine and phaseolotoxin. To elucidate the unique virulence of Psa6, we performed transcriptomic analysis of phytotoxin synthesis genes and type III effector genes in in vitro cultivation using various media. The genes related to phytotoxin synthesis and effectors of Psa6 were strictly regulated in the coronatine-inducing mediums (HS and HSC); 14 of 23 effector genes and a $h r p L$ sigma factor gene were induced at $3 \mathrm{~h}$ after transferring to the media (early-inducible genes), and phytotoxin synthesis genes such as $\arg D$ of phaseolotoxin and $c f l$ of coronatine were induced at 6 and $12 \mathrm{~h}$ after transferring to the media (late-inducible genes). In contrast, induction of these genes was not observed in the $h r p$-inducing medium. Next, to examine whether the changes in gene expression in different media is specific to Psa6, we investigated gene expression in other related bacteria. For Psa biovar 1 (Psa1), biovar 3 (Psa3), and P. s. pv. glycinea (Psg), no clear trends were observed in expression behavior across various culture media and incubation times. Therefore, Psa6 seems to exert its virulence efficiently by using two phytotoxins and effectors according to environmental changes. This is not seen in other biovars and pathovars, so it is thought that Psa6 has acquired its own balance of virulence. 


\section{Introduction}

42 Kiwifruit belong to the family Actinidiaceae and the genus Actinidia. They include Actinidia

43

44

45

46

47

48

49

50

51

52

53

54

55

56

57

58

59

60

61

62

63

64

65

66

67

68

69

70

71

72

73

74

75

76

77

78 deliciosa, a species whose flesh is green, and A. chinensis, a species whose flesh is yellow or red. In Japan, kiwifruit seedlings were first introduced from New Zealand in the 1970s and are now popular as edible fruit (Ushiyama, 1993). However, around 1980, kiwifruit bacterial canker broke out and caused serious damage to kiwifruit production (Takikawa et al., 1989). Since then, this disease has resulted in economic and productive damage in kiwifruit orchards throughout Japan.

The pathogen that causes kiwifruit bacterial canker is Pseudomonas syringae pv. actinidiae (Psa). It has been further classified into biovar 1, 2, 3, 5, and 6, reflecting its physiological and genetic diversity (Chapman, et al., 2012; Fujikawa \& Sawada, 2016; 2019; Sawada \& Fujikawa, 2019a; 2019b). In Japan, Psa is highly diverse, with significant differences in the types or presence of phytotoxins produced among biovars (Sawada \& Fujikawa, 2019a; $2019 b$ ). In general, the plant pathogenic bacteria group, $P$. syringae, is highly differentiated in pathogenicity, and it is known to have more than 60 different pathovars with different host plants and symptoms (Sawada, 2014). However, of all known P. syringae pathogens, only Psa biovar 6 (Psa6) has been reported to produce two phytotoxins (coronatine and phaseolotoxin) simultaneously. Phytotoxins are known to be important factors in the virulence of plant pathogens because they have a significant effect on plants, even at low concentrations (Bender, 1999; Strange, 2007). Coronatine, a phytotoxin produced by Psa6, is structurally similar to the plant hormone jasmonic acid (Geng et al., 2014). It has been reported to inhibit host defense responses by disrupting hormonal signals and reopening closed stomata (Geng et al., 2014). Phaseolotoxin, another phytotoxin produced by Psa6, has been shown to induce halos around lesions in leaves by inhibiting the function of ornithine carbamoyltransferase, which is an enzyme involved in arginine biosynthesis in host plants (Mitchell, 1976; Patil et al., 1976; Tamura et al., 2002). These phytotoxins have been extensively studied, and the conditions under which they are induced have been clarified in some bacteria. For example, P. syringae pv. glycinea (Psg), which is a causal pathogen of soybean (Glycine max), produces coronatine when cultured in HS and HSC medium (Hoitink \& Sinden, 1970; Palmer \& Bender, 1993), and $P$. syringae pv. phaseolicola, which is a causal pathogen of the common bean (Phaseolus vulgaris), produces the highest amounts of phaseolotoxin at $18^{\circ} \mathrm{C}$ (Nüske \& Fritsche, 1989).

In addition to the two phytotoxins, Psa6 produces other virulence factors, type III effector proteins. Effectors are known to suppress or interfere with the plant's defense response, increasing the pathogen's virulence (Jones \& Dangl, 2006). The type III secretion system is a specialized molecular machine of gram-negative bacteria that allows the effector proteins to be injected directly into the plant host cells (Coombes, 2009). Effector genes of Psa6 in the early stages of infection can be classified into several groups based on differences in expression patterns (Fujikawa \& Sawada, 2019). Although the core genome sequences of Psa are almost the 
79

80

81

82

83

84

85

86

87

88

89

90

91

92

93

94

95

96

97

98

99

100

101

102

103

104

105

106

107

108

109

110

111

112

113

114

115

116

117

118

same among biovars, the presence and combination of phytotoxins and effector genes are diverse. Therefore, the diversity of effectors and phytotoxins may be due to accessory genomes encoded by transposons and other mobile genetic elements (Sawada \& Fujikawa, 2019a; 2019b).

It is important to understand the survival strategies, evolution, and natural adaptations of Psa. In particular, determining the expression behavior of the two phytotoxin synthesis genes and effector genes of Psa6 can provide important information. We used RNA sequencing (RNA-seq) and reverse transcription-quantitative PCR (RT-qPCR), to perform transcriptomic analysis of these genes when cultured under phytotoxin-inducing or effector-inducing conditions.

\section{Materials \& Methods}

\section{Bacterial strains, media, and culture conditions}

Psa6 MAFF 212134, Psa1 MAFF 302145, Psa3 MAFF 212104, and Psg MAFF 301683 were used as the representative strains. These strains can be obtained from NARO Genebank (https://www.gene.affrc.go.jp/index_en.php). For the pre-culture, each strain was scraped from LB (Bertani, 1951) solid medium and was transferred to new LB liquid media. The cultures were then shaken overnight. After shaking, the pre-cultures were centrifuged at $6,000 \times g$ for $5 \mathrm{~m}$, then each pellet was resuspended with water to OD $(660 \mathrm{~nm})=0.6$. Two milliliters of resuspension were inoculated into $15 \mathrm{~mL}$ of respective test media and the cultures were shaken at $160 \mathrm{rpm}$ at 27 or $18{ }^{\circ} \mathrm{C}$. As test media, LB medium, HS medium, HSC medium, and $h r p$-inducing medium were used (Table 1). HS and HSC media have been reported to activate coronatine production of Psg (Hoitink \& Sinden, 1970; Palmer \& Bender, 1993). On the other hand, hrp-inducing medium has been reported to induce the expression of hrp genes and effector genes of Psg (Huynh et al., 1989). Additionally, it has been reported that cultures at $18{ }^{\circ} \mathrm{C}$, compared to $27^{\circ} \mathrm{C}$, induce the production of phytotoxins such as coronatine and phaseolotoxin (Nüske \& Fritsche, 1989; Palmer \& Bender, 1993). After incubation at 0,3,6, and $12 \mathrm{~h}, 1 \mathrm{~mL}$ of each culture was taken and used for extraction of DNA or RNA.

\section{DNA and RNA extraction}

DNA was extracted using the DNeasy mini kit (QIAGEN, Hilden, Germany) and RNA was extracted using the RNeasy mini kit (QIAGEN). DNA was used to confirm primer design, and RNA was used for RNA-Seq and RT-qPCR.

\section{RNA-Seq}

RNA-Seq was performed according to our previous study (Fujikawa \& Sawada, 2019). Briefly, total RNA was extracted from the $3 \mathrm{~h}$ culture in HS or HSC media at $27{ }^{\circ} \mathrm{C}$ or $18{ }^{\circ} \mathrm{C}$, were treated with the RiboMinus Transcriptome Isolation Kit for bacteria (Thermo Fisher Scientific Inc., Waltham, MA, USA), and rRNAs were almost depleted from the total RNAs. The RNA-Seq library was constructed from sample RNAs using the Ion Total RNA-Seq Kit v2 (Thermo Fisher Scientific Inc.) and Ion Xpress RNA-Seq barcode (Thermo Fisher Scientific Inc.). Subsequently, 
119 the RNA-Seq templates were prepared using the Ion PGM Hi-Q View OT2 Kit (Thermo Fisher 120 Scientific Inc.) on an Ion OneTouch 2 system. The templates were sequenced with an Ion PGM 121 Hi-Q View Sequencing Kit (Thermo Fisher Scientific Inc.) and a 318 Chip Kit v2 (Thermo 122 Fisher Scientific Inc.) on an Ion PGM next generation sequencer. Sequence data were analyzed

123

124

125

126

127

128

129

130

131

132

133

134

135

136

137

138

139

140

141

142

143

144

145

146

147

148

149

150

151

152

153

154

155 as RNA reads using the CLC Genomics Workbench ver. 11 (QIAGEN) and the statistical software $R$ ver. 3.5.1 with various packages (edgeR, limma, and gplots) according to a previous report (Fujikawa \& Sawada, 2019). Namely, using high-quality sequence reads with the reference genome of Psa6 MAFF 212134 (accession no. MSBW00000000), the reads per kilobase of exon per million mapped reads (RPKM) values were obtained and normalized. Then, using $R$ software, the gene expression values relative to the $27{ }^{\circ} \mathrm{C} \mathrm{HS}$ medium were calculated to $\log _{2}$ values of fold change $\left(\log _{2} \mathrm{FC}\right)$ with FDR (false discovery rate) values and each effect size (eta squared) values under the four culture conditions.

For the RT-qPCR analysis, reference gene candidates were selected according to the following conditions: (1) low FC (fold change) value, which means that expression is not strongly affected by culture conditions ( $\log _{2} \mathrm{FC}=\leq \pm 0.2$ ), and (2) high and stable CPM (counts per million) value (sum of $\log _{2} \mathrm{CPM}$ ). When genes meeting the above conditions were found, primers were designed and used for RT-qPCR analysis.

\section{RT-qPCR}

For RT-qPCR analysis, cDNA was synthesized from total RNA of each culture sample using the PrimeScript II 1st strand cDNA Synthesis Kit (Takara Bio, Shiga, Japan) with random hexamers to yield a total volume of $20 \mu \mathrm{L}$. Then, $180 \mu \mathrm{L}$ of nuclease-free water was added to bring the total volume to $200 \mu \mathrm{L}$. The synthesized cDNA was subjected to RT-qPCR using TB Green Premix Ex Taq II (Takara Bio). The PCR conditions were set as follows: denaturation at $96{ }^{\circ} \mathrm{C}$ for $10 \mathrm{~m}$; a cycle of $96^{\circ} \mathrm{C}$ for $15 \mathrm{~s}, 58^{\circ} \mathrm{C}$ for $30 \mathrm{~s}$, and $72{ }^{\circ} \mathrm{C}$ for $1 \mathrm{~m}$, repeated 40 times; then 96 ${ }^{\circ} \mathrm{C}$ for $15 \mathrm{~s}, 58^{\circ} \mathrm{C}$ for $1 \mathrm{~m}$, and $95{ }^{\circ} \mathrm{C}$ for $15 \mathrm{~s}$ to form a melting curve. DNA of Psa 6 was used as a positive control and nuclease-free water was used as a negative control. Then, based on the results of RNA-Seq (described above) we selected the genes that had similar expression levels across all culture conditions as reference genes for each bacterium. According to the method of Smith et al. (2018), RT-qPCR results were processed using the following equation:

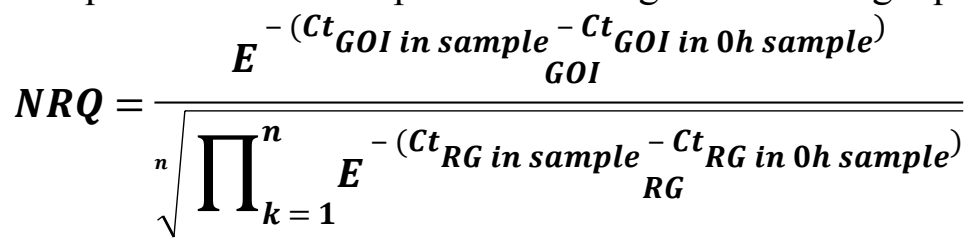

.....(1)

Where NRQ is the normalized relative quantity, $E$ is amplification efficiency of qPCR, GOI is gene of interest, and $\mathrm{RG}$ is reference gene

To solve the NRQ ( $\Delta \Delta \mathrm{Ct}$ value), a geometric mean was calculated from the RT-qPCR results of three reference genes as shown by the denominator equation, and $\Delta \mathrm{Ct}$ of each sample was calculated based on it. Then, $\Delta \Delta \mathrm{Ct}$ for each condition was calculated on the basis of the RT- 
156

157

158

159

160

161

162

163

164

165

166

167

168

169

170

171

172

173

174

175

176

177

178

179

180

181

182

183

184

185

186

187

188

189

190

191

192

193

194

195

qPCR result for $0 \mathrm{~h}$ inoculation under each condition. Moreover, the results of RT-qPCR analysis were clustered using the unweighted pair group method with arithmetic mean (UPGMA) and output to heat maps using $R$ (ver. 3.5.1) software with two packages (Heatplus, and viridis).

\section{PCR primers}

Primers were designed and tested for the following: coronatine synthesis-related genes ( $c f l, c f a l$, cfa5, cfa9, cmaD, cmaU, corR, corS, and $\operatorname{cor} P$ ); phaseolotoxin synthesis-related genes ( $\operatorname{argK}$ and $\operatorname{argD}$ ); and type III effector and related genes (avrD1, avrE1, avrpto5, avrRpm1, avrRps4, hopAA1-1, hopAE1, hopAH1, hopAI1, hopAS1, hopAU1, hopAZ1, hopD1, hopJ, hopM1, hopN, hopQ1, hopR1, hopS2, hopY1, hopZ3, hrpK, and $h r p L$ ) (Table S1). The primers for the five selected reference genes (details above) were also designed. These were "50S ribosomal protein L13", "bifunctional glutamine synthetase adenylyltransferase/deadenyltransferase", "tRNA dihydrouridine (20/20a) synthase dusA", "transcriptional regulator ftrA", and "microcin ABC transporter ATP-binding protein". It was confirmed that these primer sets can be applied not only to Psa6 but also to Psa1 (excluding the coronatine gene) and Psa3 (excluding the two phytotoxin genes) equally (Fig S1). The similar primer sets were also designed for the Psg homolog genes (Table S1).

To confirm the validity of the designed primers, the extracted DNA was subjected to PCR using Takara Ex Taq Hot Start Version (Takara Bio) with the following conditions: denaturation at $95^{\circ} \mathrm{C}$ for $10 \mathrm{~min}$; a cycle of $95^{\circ} \mathrm{C}$ for $30 \mathrm{~s}, 65^{\circ} \mathrm{C}$ for $30 \mathrm{~s}$, and $72^{\circ} \mathrm{C}$ for $1 \mathrm{~m}$, repeated 40 times; and extension at $72{ }^{\circ} \mathrm{C}$ for $7 \mathrm{~m}$. It was confirmed that respective amplicons were single bands by electrophoresis (Fig S1), and each melt peak of single band using melt curve analysis was also measured (Table S1). In addition, each amplification efficiency of primer sets was calculated (Table S1). These appropriate primer sets were used for RT-qPCR analysis.

\section{Results and Discussion}

\section{Gene expression of Psa6 under different culture conditions using RNA-Seq analysis} RNA-Seq data of Psa6 was archived in NCBI GEO (accession no. GSE149743). RNA-Seq of Psa6 revealed the behavior of 5,796 genes (Table S2). The expression values from the HS medium at $27{ }^{\circ} \mathrm{C}$ were used to calculate the expression values from the $\mathrm{HS}$ medium at $18{ }^{\circ} \mathrm{C}$ and the $\mathrm{HSC}$ medium at 27 and $18{ }^{\circ} \mathrm{C}$. Seventy-eight genes had an FDR value lower than 0.1 (Table 1). In contrast to the HS medium at $27^{\circ} \mathrm{C}, 26$ genes were induced in the HSC medium at $18^{\circ} \mathrm{C}$, including the type III chaperone $\mathrm{ShcN}$ protein gene and the type III effector (translocator) $h r p K$. In particular, $h r p K$ had a large effect size (0.96). However, there was no significant induction of other type III effector genes. In addition, neither the induction nor the suppression of genes involved in toxin production was observed. In contrast to HS medium at $27{ }^{\circ} \mathrm{C}, 17$ genes were suppressed in both the HSC medium and the $18{ }^{\circ} \mathrm{C}$ condition; however, no genes thought to be involved in virulence were significant (Table 2). Similarly, no virulence genes were significantly induced or suppressed under the different culture conditions. The HSC medium is an 
196

197

198

199

200

201

202

203

204

205

206

207

208

209

210

211

212

213

214

215

216

217

218

219

220

221

222

223

224

225

226

227

228

229

230

231

232

233

234

235

improvement of the HS medium and induces coronatine production (Palmer \& Bender, 1993). However, we found no significant change in the expression of phytotoxin genes. This suggests limited coronatine synthesis in the $3 \mathrm{~h}$ incubation of Psa6. Incubation of $P$. syringae at $18^{\circ} \mathrm{C}$ can induce phytotoxin production compared with incubation at $27^{\circ} \mathrm{C}$ (Nüske \& Fritsche, 1989; Palmer \& Bender, 1993), but we did not observe significant induction of phytotoxins under those conditions (Table 2). This suggests that temperature in a $3 \mathrm{~h}$ incubation may have little effect on phytotoxin production for Psa6. To clarify the role of temporal changes in the behavior of virulence genes, such as type III effector genes and phytotoxin synthesis genes, we examined the behavior of gene expression over time using RT-qPCR analysis. Because the relative expression values in RT-qPCR analyses are calculated using constantly expressed reference genes, the selection of appropriate reference genes is important. Based on the conditions described in the Materials and Methods section, we selected five candidates among a total of 5,796 genes (Table $\mathrm{S} 3$ ). From these five genes (50S ribosomal protein L13, bifunctional glutamine synthetase adenylyltransferase/deadenyltransferase, tRNA dihydrouridine (20/20a) synthase $d u s A$, transcriptional regulator ftr $A$, and microcin ABC transporter ATP-binding protein), three genes for each bacterium were used as reference genes. For these genes, expression level was high and stable (expression change was low), regardless of the media used. Thus, we designed primers for the RT-qPCR analysis based on the sequences of the following reference genes: 50S ribosomal protein L13, bifunctional glutamine synthetase adenylyltransferase/deadenyltransferase, and tRNA dihydrouridine (20/20a) synthase $d u s A$ for Psa6; 50S ribosomal protein L13, bifunctional glutamine synthetase adenylyltransferase/deadenyltransferase, and transcriptional regulator ftr $A$ for Psa1 and Psa3; and 50S ribosomal protein L13, bifunctional glutamine synthetase adenylyltransferase/deadenyltransferase, and microcin ABC transporter ATP-binding protein for Psg (Table S1). Since these reference genes are a group of genes with stable expression and housekeeping, it is expected that strains other than Psa6 have similar expression tendencies. In addition, it is expected that internal control can be guaranteed by the geometric mean of 3 kinds of genes in order to avoid the bias of expression of each gene.

\section{Temporal changes in the expression of virulence genes of Psa6 in RT-qPCR analysis}

The expression of phytotoxin synthesis genes and type III effector genes of Psa6 was investigated with RT-qPCR. Normalization was performed using the reference genes selected above.

For the reference genes, the amplification efficiency $(E)$ of target genes in qPCR was approximately 2.0 (Table S1) and three genes were used as the reference $(n=3)$. Thus, using equation (1) in the Materials and Methods section with each $E$ of primer sets, the relative expression levels were calculated from the $\mathrm{Ct}$ value at a certain time and the $\mathrm{Ct}$ value at $0 \mathrm{~h}$. Here, in order to indicate that the results of RNA-Seq and the results of RT-qPCR did not diverge significantly, the expression levels of the virulence genes in the RT-qPCR analysis for Psa6 and the expression levels of the same genes in the RNA-Seq analysis were compared (Table S4). When the expression levels of the virulence genes from RNA-Seq were plotted on the vertical 
236

237

238

239

240

241

242

243

244

245

246

247

248

249

250

251

252

253

254

255

256

257

258

259

260

261

262

263

264

265

266

267

268

269

270

271

272

273

274

axis and those from RT-qPCR were plotted on the horizontal axis, both RNA-Seq and RT-qPCR results were correlated (Fig. 1). The plots were concentrated in the first and third quadrants $\left(\mathrm{R}^{2}\right.$ (coefficient of determination) value is about 0.6), although some genes were expressed differently. We concluded that the results from RT-qPCR can almost function as a representation of transcriptome analysis.

The expression of phytotoxin synthesis genes and effector-related genes of Psa6 under various culture conditions with different incubation times was investigated using RT-qPCR (Table S5 \& Data S1). From the results of RT-qPCR analysis, heat maps were output (Fig. 2). We found that phytotoxin synthesis genes and effector genes of Psa6 were induced in HS and HSC media (Fig. 2A), which are known to induce coronatine production. In contrast, these genes were not induced in the $h r p$-inducing medium, which is known to induce hrp-dependent effector genes. The LB and $h r p$-inducing media were clustered together and were separate from the HS and HSC media. In the LB and $h r p$-inducing media cluster, most genes were suppressed. Moreover, in the hrp-inducing medium, no clear induction of the hrpL-dependent effector genes of Psa6 was observed. On the other hand, phytotoxin synthesis genes and effector genes were significantly induced in HS and HSC media. Additionally, incubation at $18^{\circ} \mathrm{C}$ and $27^{\circ} \mathrm{C}$ did not result in significant changes to gene expression; samples from each temperature were clustered separately. This suggests that culture medium composition and incubation time have a stronger effect on Psa6 cultivation than incubation temperature.

Intriguingly, the expression of virulence genes was generally separated into the following two groups: early-inducible genes and late-inducible genes (Fig. 2). This was more clearly observed in the heat map, excluding the conditions of $h r p$-inducing medium (Fig. 2B). The early-inducible genes (hrpL, avrD1, avrpto5, avrRpm1, hopAA1-1, hopAE1, hopAU1, hopAZ1, hopM1, hopN1, hopQ1, hopR1, hopS2, hopY1, hrpK, and $\operatorname{argK}$ ) were induced after $3 \mathrm{~h}$ of incubation but suppressed at 6 and $12 \mathrm{~h}$. Most of them were thought to be $h r p L$-dependent effector genes (Lam et al., 2014; Vencato et al., 2006). The early-inducible genes of Psa6 contains hrpL and several effector genes. It is known that the HrpL protein binds to the Hrp box promoter sequence on the upper region of protein-encoding sequences in several effector genes (Greenberg \& Yao, 2004; Lam et al., 2014), then, we could also find the Hrp box promoter sequences in some earlyinducible genes of Psa6 (Fig S2). Therefore, HrpL regulation may be involved in the earlyinducible genes of Psa6 in response to HS and HSC media. However, further research is needed on this detail. In contrast, the late-inducible genes (avrE1, avrRps4, hopAH1, hopAI1, hopAS1, hopD1, hopJ, hopZ3, cfl, cfal, cfa5, cfa9, cmaD, cmaU, corP, corR, corS, and $\arg D$ ) were induced after $6 \mathrm{~h}$ of incubation. These genes included phytotoxin synthesis genes, except $\arg K$ and some effector genes. Thus, when Psa6 is incubated under phytotoxin-induced conditions (HS and HSC media), induction of phytotoxin synthesis genes followed that of effector genes. In addition, phytotoxin synthesis genes were expressed for longer than the hrpL-regulated effectors.

\section{Comparison of gene expression behavior between Psa6 and other bacteria}

Peer] reviewing PDF | (2020:04:48372:1:1:NEW 15 Jun 2020) 
275 As described above, in Psa6, the effector genes are not induced in the $h r p$-inducing medium, and 276 the induction of virulence genes in phytotoxin-inducing media is strictly controlled over time. It 277 was unclear whether these behaviors of gene expression were Psa6 specific; thus, similar tests 278 were performed on the other bacteria. The expressions of virulence genes in two biovars (Psa1 279 and Psa3) and one other species (Psg) were investigated using RT-qPCR (Table S6 \& Data S2). 280 Normalization was performed using the reference genes selected above. The expression level of 281 virulence genes was compared across all bacteria. Heat maps were generated from the expression 282 patterns of the effector genes shared by each bacterium (Fig. 3). Psa1 and Psa3 were nested in 283 the heat map (Fig. 3A). In Psa6, the expression of effector genes was significantly induced 284 compared with other bacteria. Furthermore, Psg was scattered in clusters of Psa1 and Psa3, and

285

286

287

288

289

290

291

292

293

294

295

296

297

298

299

300

301

302

303

304

305

306

307

308

309

310

311

312

313

314 the clusters did not split due to differences in pathovars. When clustering was performed with only common effectors of both Psa1 and Psa3 (omitting Psa6 and Psg), medium composition had no effect on gene expression (Fig. 3B). Our results show that medium composition and incubation time did not significantly affect the expression of effector genes in Psa1, Psa3, or Psg.

We also compared phytotoxin synthesis genes of Psa6 with other bacteria. To compare the expression of coronatine synthesis genes in Psa6 and Psg, the expression levels of cfal and $c m a D$ at 0,3 , and $6 \mathrm{~h}$ incubation were examined (Table 3 ). The results showed that incubation of Psa6 in HS and HSC media induced the expression of $c f a 1$ and $c m a D$ over time, but incubation in LB and $h r p$-inducing media significantly suppressed $c f a l$ and slowly induced the expression of $\mathrm{cmaD}$. Therefore, the behavior of the coronatine synthesis genes of Psa6 was affected by the medium composition. On the other hand, Psg was not affected by medium composition. In Psg, there were no differences in gene expression across the different media, and only $c f a 1$ was induced over time regardless of medium composition. There was no induction or suppression of $\mathrm{cmaD}$. Additionally, we compared the expression of phaseolotoxin synthesis-related genes in Psa6 and Psa1 (Table 4). In Psa6, the expression of $\arg K$ and $\arg D$ was slowly induced by culture in HS and HSC media. In addition, the expression of $\operatorname{argK}$ was notably induced and $\arg D$ was greatly suppressed in LB and $h r p$-inducing media. However, in Psal, $\arg K$ was induced in LB and $h r p$-inducing media, and $\arg D$ remained expressed at a constant level without induction or suppression. In summary, the coronatine and phaseolotoxin synthesis genes in Psa6 differed in their response to medium composition and incubation time compared to other bacteria, with a particularly strong effect of medium composition.

\section{Expression patterns and conditions of the virulence genes in Psa6}

Coronatine production in Psg PG 4180 is more active in cultures at $18^{\circ} \mathrm{C}$ than $24^{\circ} \mathrm{C}$ or higher (Palmer \& Bender, 1993). In contrast, coronatine production in P. syringae pv. tomato (Pto) DC 3000 is temperature independent and constant (Braun et al., 2008). Additionally, seven strains of P. syringae, including Psg PG 4180, Psg 7a, and Pto PT 23.2, produce more coronatine in HSC medium than in HS medium (Palmer \& Bender, 1993). However, two strains of $P$. syringae pv. maculicola 438 and Pst DC 3000 do not produce coronatine in HSC medium (Palmer \& Bender, 1993). Moreover, in Psg PG 4180, the CmaB protein, a synthesis protein of coronatine, decreases 
$3154 \mathrm{~h}$ after the temperature is changed from $18{ }^{\circ} \mathrm{C}$ to $28^{\circ} \mathrm{C}$, suggesting that changes in gene

316

317

318

319

320

321

322

323

324

325

326

327

328

329

330

331

332

333

334

335

336

337

338

339

340

341

342

343

344

345

346

347

348

349

350

351

352

353

354

expression can be observed at an earlier stage (Budde et al., 1998). However, the coronatine synthesis genes of Psa6 were induced later, regardless of temperature (Fig. 2). Thus, the coronatine synthesis genes of Psa6 may be regulated by different environmental conditions than Psg PG 4180. In addition, in the strain of Psg used in this study (MAFF 301683), which was isolated in Japan, the expression of the coronatine synthesis genes was induced regardless of medium composition (Table 3). Conversely, in a different Psg strain, PG 4180, coronatine synthesis was induced in HS and HSC media (Palmer \& Bender, 1993). Thus, depending on the type of Pseudomonas (pathovars and strains), coronatine production is thought to be affected by various environmental conditions.

Moreover, despite Psa6 and Psa1 possessing a similar phaseolotoxin synthesis gene cluster (Fujikawa \& Sawada, 2019), both expressed them differently (Table 4). This gene cluster is contained in the tox island in the genomes of Psa6 and Psa1. However, in Psa6, the gin $A B C D$ operon, which is located at the left end of the tox island and is involved in the excision/insertion of the tox island, was truncated, suggesting that the island of biovar 6 might have lost its mobility (Fujikawa \& Sawada, 2019). At present, it is unknown whether the expression pattern of the phaseolotoxin synthesis genes is different due to differences in the gin $A B C D$ operon or whether it depends on another regulation system. This requires further investigation.

We found that Psa6 did not induce $h r p L$-dependent effectors in the $h r p$-inducing medium but was induced in HS and HSC media (Fig. 2). The hrp-inducing medium is an oligotrophic medium (Huynh et al., 1989), but HS and HSC media contain rich sugars and minerals (Palmer \& Bender, 1993). In Psa6, phytotoxin production and effector-related genes were induced similarly even with different concentrations of glucose $(10 \mathrm{~g} / \mathrm{L}$ in HS medium and $20 \mathrm{~g} / \mathrm{L}$ in HSC medium) (Table 1). However, fructose $(1.8 \mathrm{~g} / \mathrm{L})$ in the $h r p$-inducing medium was not significantly induced. This may be due to qualitative or quantitative differences in carbon sources. Additionally, it seemed that the $\mathrm{FeCl}_{3}$ concentration (HS, HSC, and the $h r p$-inducing media) (Table 1) may not be involved in the expression behavior of phytotoxin synthesis genes and effector genes. In this study, HS and HSC media were found to induce the virulence genes of Psa6. These genes were divided into two groups according to how long it took for them to be induced.

The early-inducible genes included many effectors and $h r p L$. The effectors in this group are involved in plant immunity such as pathogen-associated molecular patterns (PAMPs) triggered immunity (PTI) and effector-triggered immunity (ETI) (Jones \& Dangl, 2006). PTI is a plant immune system that responds to the cellular components carried by pathogens such as flagella protein and elongation factor. A plant immune system activated by PTI induces various antimicrobial molecules such as salicylic acid and PR (pathogenesis-related) proteins, resulting in the inhibition of pathogen spread. In response, pathogens can interfere with PTI by injecting the effectors to avoid the plant defense. However, plants have ETI, another plant immune system, which responds to the effectors. Thus, the plant immune system is expressed as a zigzag

Peer) reviewing PDF | (2020:04:48372:1:1:NEW 15 Jun 2020) 
355

356

357

358

359

360

361

362

363

364

365

366

367

368

369

370

371

372

373

374

375

376

377

378

379

380

381

382

383

384

385

386

387

388

389

390

391

392

393

394

model (Jones \& Dangl, 2006). Although the function of these effectors in Psa6 to the host plants is unknown, these homologous proteins have been reported as follows; AvrPto5, contained in the early-inducible gene of Psa6, induces PTI, whereas HopS, HopAA1, and HopM1 inhibit PTI. In addition, AvrPto5, AvrRpm1, and HopD induce ETI, whereas HopD, HopN, and HopS suppress ETI (Lindeberg et al., 2012).

In contrast to the early-inducible genes, the late-inducible genes included phytotoxin synthesis-related genes other than $\arg K$. Because it has been reported that coronatine and other phytotoxins accumulate over time (Palmer \& Bender, 1993), phytotoxin synthesis-related genes may require longer periods than most effector genes for expression. On the other hand, the $\arg K$ gene of Psa6 was an early inducible gene. Because $\arg K$ is also known to be involved in the production of phaseolotoxin-insensitive ornithine carbamoyltransferase (Sawada et al., 1997), this early expression may lead to resistance to phaseolotoxin and subsequent phaseolotoxin production. Additionally, some effector genes were listed in the late-inducible genes. It is known that AvrE and AvrRps4 in Pto suppress PTI (Lindeberg et al., 2012), while HopZ3, AvrRps4, HopAS1, and HopAI1 induce ETI (Lewis et al., 2014; Lindeberg et al., 2012; Sohn, Zhang \& Jones, 2009; Sohn et al., 2012), and HopZ suppresses ETI in Arabidopsis (Lindeberg et al., 2012). These late-inducible genes in Psa6 may also trigger ETI, such as the Pto-Arabidopsis interaction. However, it is thought to function under conditions different from those of the earlyinducible genes, for example, at different times, in different environment, and with different hosts.

The coronatine synthesis genes of Psa6 are located on plasmids whose sequences are highly homologous to those of Psa2 and Psg (Fujikawa \& Sawada, 2019). The phaseolotoxin production genes of Psa6 are located on the tox island in the genome, and it is thought that the region was originally in another bacterium and transferred to Psa1 and Psa6 through horizontal gene transfer (Sawada, 2016; Fujikawa \& Sawada, 2019). In addition, along with the presence or absence of virulence factors, it was suggested that the regulation of gene expression varied also among pathovars and biovars. Phytopathogenic bacteria are then thought to have coevolved with plants, with their behavior and infection method related to the life cycle of the host plant. Psa6, with two phytotoxins, was unique not only in its physiological characteristics but also in the expression behavior of phytotoxin synthesis genes and effector genes. Although the relationship between the number of virulence factors and their expression behavior is still not clear, we propose that strict gene expression is thought to have been acquired with the acquisition of many virulence factors. The behavior of virulence genes in Psa clarified in this study will help elucidate the differences in virulence and survival strategies among biovars.

\section{Conclusions}

Pseudomonas syringae pv. actinidiae biovar 6 (Psa6) is a causal agent of kiwifruit bacterial canker and is a unique plant pathogenic bacterium, producing two types of phytotoxins, coronatine and phaseolotoxin. We investigated the expression behavior of virulent genes of Psa6 under various culture conditions. The expression pattern of phytotoxin synthesis genes in Psa6

Peer] reviewing PDF | (2020:04:48372:1:1:NEW 15 Jun 2020) 
395

396

397

398

399

400

401

402

403

404

405

406

407

408

409

410

411

412

413

414

415

416

417

418

419

420

421

422

423

424

425

426

427

428

429

430

431

432

433

434

435

436

was different from that of another pathovar, P. s. pv. glycinea, which produces coronatine, and another biovar, Psa1, which produces phaseolotoxin. In addition, the expression of virulence genes (phytotoxin synthesis genes and type III effector genes) was induced in the coronatineproducing media regardless of temperature, and confirmed that the expression behavior had two patterns: early-inducible and late-inducible (Fig. 4). The expression behavior of virulence genes of Psa6 clarified in this study will contribute to elucidating the virulence of Psa to kiwifruits and survival strategies among Psa biovars and plant pathogenic Pseudomonas.

\section{Acknowledgements}

We are grateful to Dr. Takako Ishiga, Ms. Mariko Taguchi, Ms. Akane Sasaki, and Ms. Hiroe Hatomi for their support with the experiments. We also thank the members of the Laboratory of Plant Parasitic Mycology, University of Tsukuba, and the members of IFTS-NARO for their helpful discussions. We would like to thank Editage (www.editage.com) for English language editing.

\section{References}

Bender CL 1999. Chlorosis-inducing phytotoxins produced by Pseudomonas syringae. Eur J Plant Pathol 105(1): 1-12 DOI 10.1023/A:1008692227307.

Bertani G 1951. Studies on lysogenesis. I. the mode of phage liberation by lysogenic Escherichia coli. J Bacteriol. 62(3): 293-3000.

Braun Y, Smirnova AV, Schenk A, Weingart H, Burau C, Muskhelishvili G, Ullrich MS. 2008. Component and protein domain exchange analysis of a thermoresponsive, twocomponent regulatory system of Pseudomonas syringae. Microbiology 154(9): 27002708 DOI 10.1099/mic.0.2008/018820-0.

Budde IP, Rohde BH, Bender CL, Ullrich MS. 1998. Growth phase and temperature influence promoter activity, transcript abundance, and protein stability during biosynthesis of the Pseudomonas syringae phytotoxin coronatine. Journal of bacteriology 180(6): 13601367.

Chapman JR, Taylor RK, Weir BS, Romberg MK, Vanneste JL, Luck J, Alexander BJ. 2012. Phylogenetic relationships among global populations of Pseudomonas syringae pv. actinidiae. Phytopathology 102(11): 1034-1044 DOI 10.1094/PHYTO-03-12-0064-R.

Coombes BK. 2009. Type III secretion systems in symbiotic adaptation of pathogenic and nonpathogenic bacteria. Trends Microbiol 17(3): 89-94 DOI 10.1016/j.tim.2008.11.006.

Fujikawa T, Sawada H. 2016. Genome analysis of the kiwifruit canker pathogen Pseudomonas syringae pv. actinidiae biovar 5. Sci Rep 6: 21399 DOI 10.1038/srep21399.

Fujikawa T, Sawada H. 2019. Genome analysis of Pseudomonas syringae pv. actinidiae biovar 6, which produces the phytotoxins, phaseolotoxin and coronatine. Sci Rep 9: 3836 DOI 10.1038/s41598-019-40754-9.

Geng X, Jin L, Shimada M, Kim MG, Mackey D. 2014. The phytotoxin coronatine is a 
437

438

439

440

441

442

443

444

445

446

447

448

449

450

451

452

453

454

455

456

457

458

459

460

461

462

463

464

465

466

467

468

469

470

471

472

473

474

475

476

477

478

479

480

481

482

multifunctional component of the virulence armament of Pseudomonas syringae. Planta 240(6): 1149-1165 DOI 10.1007/s00425-014-2151-X.

Greenberg JT, Yao N. 2004. The role and regulation of programmed cell death in plant-pathogen interactions. Cell Microbiol 6(3): 201-211 DOI 10.1111/j.1462-5822.2004.00361.x.

Hoitink HA, Sinden SL. 1970. Partial purification and properties of chlorosis inducing toxins of Pseudomonas phaseolicola and Pseudomonas glycinea. Plant Pathology 60(8): 12361237 DOI 10.1094/Phyto-60-1236.

Huynh TV, Dahlbeck D, Staskawicz BJ. 1989. Bacterial blight of soybean: regulation of a pathogen gene determining host cultivar specificity. Science 245(4924): 1374-1377 DOI 10.1126/science. 2781284 .

Jones JD, Dangl JL. 2006. The plant immune system. Nature 444: 323-329 DOI 10.1038/nature05286.

Lam HN, Chakravarthy S, Wei HL, BuiNguyen H, Stodghill PV, Collmer A, Swingle BM, Cartinhour SW. 2014. Global analysis of the HrpL regulon in the plant pathogen Pseudomonas syringae pv. tomato DC3000 reveals new regulon members with diverse functions. PLoS One 9(8): e106115 DOI 10.1371/journal.pone.0106115.

Lewis JD, Wilton M, Mott GA, Lu W, Hassan JA, Guttman DS, Desveaux D. 2014. Immunomodulation by the Pseudomonas syringae HopZ type III effector family in Arabidopsis. PLoS One. 2014 Dec 9(12): e116152 DOI 10.1371/journal.pone.0116152.

Lindeberg M, Cunnac S, Collmer A. 2012. Pseudomonas syringae type III effector repertoires: last words in endless arguments. Trends Microbiol 20(4): 199-208 DOI 10.1016/j.tim.2012.01.003.

Mitchell RE. 1976. Isolation and structure of a chlorosis inducing toxin of Pseudomonas phaseolicola. Phytochemistry 15(12): 1941-1947 DOI 10.1016/S0031-9422(00)88851-2.

Nüske J, Fritsche W. 1989. Phaseolotoxin production by Pseudomonas syringae pv. phaseolicola: the influence of temperature. J Basic Microbiol 29(7): 441-447 DOI 10.1002/jobm.3620290713.

Palmer DA, Bender CL. 1993. Effects of environmental and nutritional factors on production of the polyketide phytotoxin coronatine by Pseudomonas synrngae pv. glycinea. Appl Environ Microbiol. 59(5): 1619-1626.

Patil SS, Youngblood P, Christiansen P, Moore RE. 1976. Phaseotoxin A. an antimetabolite from Pseudomonas phaseolicola. Biochem Biophys Res Commun 69(4): 1019-1027 DOI 10.1016/0006-291X(76)90474-5.

Sawada H, Takeuchi T, Matsuda I. 1997. Comparative analysis of Pseudomonas syringae pv. actinidiae and pv. phaseolicola based on phaseolotoxin-resistant ornithine carbamoyltransferase gene $(\operatorname{argK})$ and $16 \mathrm{~S}-23 \mathrm{~S}$ rRNA intergenic spacer sequences. Appl Environ Microbiol 63(1): 282-288.

Sawada H. 2014. Studies on the classification and evolution of phytopathogenic bacteria of the genera Agrobacterium and Pseudomonas. [in Japanese] Jpn. J. Phytopathol. 80: 139142.

Sawada H. 2016. Characteristics of pathogens causing bacterial canker of kiwifruit in Japan. [in Japanese] Annual Report on Exploration and Introduction of Microbial Genetic Resources 25: 103-110.

Sawada H, Fujikawa T. 2019a. Genetic diversity of Pseudomonas syringae pv. actinidiae, pathogen of kiwifruit bacterial canker. Plant Pathol. 68: 1235-1248 DOI 10.1111/ppa.13040.

Peer) reviewing PDF | (2020:04:48372:1:1:NEW 15 Jun 2020) 
483

484

485

486

487

488

489

490

491

492

493

494

495

496

497

498

499

500

501

502

503

504

505

506

507

508

509

510

511

512

513

514

515

516

517

518

519

520

521

522

523

524

525

526

Sawada H, Fujikawa T. 2019b. Genetic diversity among biovars of kiwifruit canker pathogen Pseudomonas syringae pv. actinidiae. [in Japanese, English summary] Jpn. J. Phytopathol. 85(1): 3-17 DOI 10.3186/jiphytopath.85.3.

Smith A, Lovelace AH, Kvitko BH. 2018. Validation of RT-qPCR approaches to monitor Pseudomonas syringae gene expression during infection and exposure to patterntriggered immunity. Mol Plant Microbe Interact 31(4): 410-419 DOI 10.1094/MPMI-1117-0270-TA.

Sohn KH, Saucet SB, Clarke CR, Vinatzer BA, O’Brien HE, Guttman DS, Jones JD. 2012. HopAS1 recognition significantly contributes to Arabidopsis nonhost resistance to Pseudomonas syringae pathogens. New Phytol 193(1): 58-66 DOI 10.1111/j.14698137.2011.03950.x.

Sohn KH, Zhang Y, Jones JD. 2009. The Pseudomonas syringae effector protein, AvrRPS4, requires in planta processing and the KRVY domain to function. Plant J 57(6): 10791091 DOI 10.1111/j.1365-313X.2008.03751.x.

Strange RN. 2007. Phytotoxins produced by microbial plant pathogens. Nat Prod Rep 24: 127144 DOI 10.1039/B513232K.

Takikawa Y, Serizawa S, Ichikawa T. 1989. Pseudomonas syringae pv. actinidiae pv. nov.: the causal bacterium of canker of kiwifruit in Japan. Ann Phytopath Soc Japan 55: 437-444.

Tamura A, Imamura M, Yoneyama K, Kohno Y, Takikawa Y, Yamaguchi I. 2002. Role of phaseolotoxin production by Pseudomonas syringae pv. actinidiae in the formation of halo lesions of kiwifruit canker disease. Physiol Mol Plant Pathol 60(4): 207-214 DOI 10.1006/pmpp.2002.0405.

Ushiyama K. 1993. Studies on the epidemics and control of bacterial canker of kiwifruitcaused by Pseudomonas syringae pv. actinidiae. [in Japanese, English summary] Bulletin of the Kanagawa Horticultural Experiment Station 43: 1-76 DOI 10.11501/3095787.

Vencato M, Tian F, Alfano JR, Buell CR, Cartinhour S, DeClerck GA, Guttman DS, Stavrinides J, Joardar V, Lindeberg M, Bronstein PA, Mansfield JW, Myers CR, Collmer A, Schnider DJ. 2006. Bioinformatics-enabled identification of the HrpL regulon and type III secretion system effector proteins of Pseudomonas syringae pv. phaseolicola 1448A. Mol Plant Microbe Interact 19(11): 1193-1206 DOI: 10.1094/MPMI-19-1193

\section{Figure legends}

Figure 1. Comparison of expression trends in the RNA-seq and RT-qPCR analyses. The expression levels of the virulence genes in RNA-Seq were plotted on the vertical axis and that in RT-qPCR were plotted on the horizontal axis. Most of the plots were concentrated in the first and third quadrants, while some were concentrated in the second and fourth quadrants. The yellow wavy line indicates a linear approximation, and $\mathrm{R}^{2}$ value (about 0.6 ) was obtained.

Figure 2. Heat map constructed from the expression level of virulence genes of Psa6 under each culture condition. The results of RT-qPCR analysis of Psa6 were clustered using the unweighted pair group method with arithmetic mean (UPGMA). A, Heat map of expression levels of virulence genes under each culture condition. B, Reconstructed heat map excluding the conditions of the hrp-inducing medium. Gene names highlighted in blue are phaseolotoxin 
527 synthesis genes, and gene names highlighted in yellow are coronatine synthesis genes.

528 Remaining genes are type III effectors. In heat maps, induced genes are indicated as yellow

529 boxes and suppressed genes are indicated as blue boxes.

530

531 Figure 3. Heat map constructed from the expression levels of virulence genes of Psa6, Psa1, 532 Psa3, and Psg under each culture condition. The results of RT-qPCR analysis of Psa6, Psa1,

533 Psa3, and Psg were clustered using the unweighted pair group method with arithmetic mean

534 (UPGMA). A, Heat map of expression levels of virulence genes under each culture condition. B, 535 Reconstructed heat map excluding the results of both Psa6 and Psg. In heat maps, induced genes 536 are indicated as yellow boxes and suppressed genes are indicated as blue boxes.

537

538

Figure 4. Schematic diagram of the expression pattern of Psa6 virulence genes in different media. The expression of virulence genes (type III effector genes and phytotoxin synthesis genes) of Psa6 was induced in the coronatine-producing media, and the expression behavior had

541 two patterns: early-inducible and late-inducible. These genes were suppressed or constant in LB 542 medium and the $h r p$-inducing medium. 


\section{Table $\mathbf{1}$ (on next page)}

Each composition of media used in this study 
1 Table 1. Each composition of media used in this study

2

\begin{tabular}{lcccc}
\hline Per liter of medium & HS & HSC & hrp-inducing & LB \\
\hline $\mathrm{NH}_{4} \mathrm{Cl}$ & $1.0 \mathrm{~g}$ & $1.0 \mathrm{~g}$ & & \\
$\left(\mathrm{NH}_{4}\right)_{2} \mathrm{SO}_{4}$ & & & $1.0 \mathrm{~g}$ & \\
$\mathrm{MgCl}_{2} \cdot 6 \mathrm{H}_{2} \mathrm{O}$ & & & $0.34 \mathrm{~g}$ & \\
$\mathrm{MgSO}_{4} \cdot 7 \mathrm{H}_{2} \mathrm{O}$ & $0.3 \mathrm{~g}$ & $0.2 \mathrm{~g}$ & & \\
$\mathrm{KH}_{2} \mathrm{PO}_{4}$ & $4.1 \mathrm{~g}$ & $4.1 \mathrm{~g}$ & $6.8 \mathrm{~g}$ & \\
$\mathrm{~K}_{2} \mathrm{HPO}_{4}$ & $3.6 \mathrm{~g}$ & $3.6 \mathrm{~g}$ & & \\
$\mathrm{KNO}_{3}$ & & $0.3 \mathrm{~g}$ & & $10 \mathrm{~g}$ \\
$\mathrm{NaCl}^{\mathrm{D}-\text { glucose }}$ & & & $0.1 \mathrm{~g}$ & \\
D-fructose & $10 \mathrm{~g}$ & $20 \mathrm{~g}$ & & \\
FeCl & & & & \\
Yeast extract & & & $1.8 \mathrm{~g}$ & \\
Bactopeptone & $2 \mu \mathrm{M}$ & $20 \mu \mathrm{M}$ & $20 \mu \mathrm{M}$ & \\
& & & & $5.0 \mathrm{~g}$ \\
\hline
\end{tabular}

3 
Table 2 (on next page)

List of gene expression of Psa6 in difference medium conditions by RNA-Seq analysis (FDR $<0.1$ with effect size) 
1 Table 2. List of gene expression of Psa6 in difference medium conditions by RNA-Seq analysis (FDR $<0.1$ 2 with effect size)

\begin{tabular}{|c|c|c|c|c|c|c|c|c|}
\hline ID & product & 27HSC & $18 H^{b}$ & 18HSCc & $\log C P M$ & PValue & FDR & Effect size \\
\hline BUE60_04820 & heat-shock protein & 1.355338 & -2.43875 & -1.31508 & 11.73123 & $2.29 \mathrm{E}-11$ & $1.33 \mathrm{E}-07$ & 0.825882 \\
\hline BUE60_03120 & transposase & 1.020947 & -9.70426 & 0.793676 & 11.37198 & $5.78 \mathrm{E}-11$ & $1.68 \mathrm{E}-07$ & 0.641125 \\
\hline BUE60 14130 & transposase & 0 & 0 & 9.353037 & 8.873037 & $8.51 \mathrm{E}-10$ & $1.64 \mathrm{E}-06$ & 0.59108 \\
\hline BUE60_20545 & peptidase M4 & 2.489317 & 4.443465 & 4.633089 & 9.090263 & $4.33 \mathrm{E}-08$ & $6.26 \mathrm{E}-05$ & 0.843105 \\
\hline BUE60_04770 & hypothetical protein & -0.34373 & -7.61338 & -7.61338 & 8.059493 & $5.40 \mathrm{E}-08$ & $6.26 \mathrm{E}-05$ & 0.670986 \\
\hline BUE60_01870 & phage tail protein & 7.758212 & 6.587112 & 7.860501 & 8.547592 & $3.98 \mathrm{E}-07$ & 0.000384 & 0.541496 \\
\hline BUE60_06970 & hypothetical protein & -2.58953 & -0.8029 & -8.1928 & 8.386577 & $1.29 \mathrm{E}-06$ & 0.001067 & 0.864256 \\
\hline BUE60_14400 & 4a-hydroxytetrahydrobiopterin dehydratase & 7.494481 & 7.602294 & 8.036372 & 8.691885 & $2.15 \mathrm{E}-06$ & 0.001554 & 0.56063 \\
\hline BUE60_02835 & chemotaxis protein & 2.250013 & 1.336789 & 2.235526 & 11.70462 & $2.82 \mathrm{E}-06$ & 0.001818 & 0.626422 \\
\hline BUE60_17905 & DNA-directed DNA polymerase & 0 & 9.167101 & 6.180072 & 8.399849 & $3.17 \mathrm{E}-06$ & 0.001838 & 0.721365 \\
\hline BUE60_02480 & phospholipid-binding protein & 2.75255 & 2.175321 & 2.667653 & 11.94782 & $4.11 \mathrm{E}-06$ & 0.001985 & 0.799186 \\
\hline BUE60_04310 & hypothetical protein & 0.224221 & -7.50516 & -7.50516 & 8.207357 & $3.77 \mathrm{E}-06$ & 0.001985 & 0.637833 \\
\hline BUE60_16610 & type III effector (translocator) HrpK & 0.606558 & 2.038242 & 1.196631 & 12.13895 & $4.71 \mathrm{E}-06$ & 0.002099 & 0.957299 \\
\hline BUE60_04320 & ribosomal subunit interface protein & 1.726174 & 0.111266 & 1.619895 & 11.57393 & $8.20 \mathrm{E}-06$ & 0.003394 & 0.768705 \\
\hline BUE60_28960 & transposase & 0 & 9.007053 & 7.799665 & 8.680074 & $1.35 \mathrm{E}-05$ & 0.004903 & 0.403141 \\
\hline BUE60_03115 & transposase & -0.59594 & 0.589465 & -9.83131 & 10.6735 & $1.30 \mathrm{E}-05$ & 0.004903 & 0.476177 \\
\hline BUE60_23710 & ester cyclase & 0.775814 & -6.16163 & -6.16163 & 7.36076 & $2.09 \mathrm{E}-05$ & 0.006918 & 0.599137 \\
\hline BUE60_21600 & transporter & 0 & 6.717301 & 7.851922 & 7.885333 & $2.15 \mathrm{E}-05$ & 0.006918 & 0.367771 \\
\hline BUE60_05090 & ATP-dependent chaperone ClpB & 1.973675 & -0.24943 & 0.635359 & 9.808781 & $2.36 \mathrm{E}-05$ & 0.007214 & 0.855973 \\
\hline BUE60_16865 & hypothetical protein & 0 & 7.452753 & 0 & 6.847248 & $2.67 \mathrm{E}-05$ & 0.00775 & 0.834247 \\
\hline BUE60_14380 & acetate--CoA ligase & -0.39884 & -3.76361 & -3.20795 & 8.443014 & $3.68 \mathrm{E}-05$ & 0.010001 & 0.773293 \\
\hline BUE60_12810 & $\begin{array}{l}\text { Fe/S-dependent 2-methylisocitrate dehydratase } \\
\text { AcnD }\end{array}$ & -2.44697 & -3.73661 & -4.31049 & 7.889943 & $3.80 \mathrm{E}-05$ & 0.010001 & 0.840004 \\
\hline BUE60_09615 & 50S ribosomal protein L11 & 0.386928 & 0.149426 & -6.90695 & 8.113202 & $5.79 \mathrm{E}-05$ & 0.014595 & 0.523026 \\
\hline BUE60_02595 & molecular chaperone DnaK & 1.635999 & -0.18151 & 0.473407 & 11.0735 & $6.45 \mathrm{E}-05$ & 0.015578 & 0.932595 \\
\hline
\end{tabular}




\begin{tabular}{|c|c|c|c|c|c|c|c|c|}
\hline BUE60_02495 & 30S ribosomal protein $\mathrm{S} 15$ & -0.67634 & -3.71221 & -3.52621 & 12.0987 & $7.41 \mathrm{E}-05$ & 0.017175 & 0.614689 \\
\hline BUE60_21040 & ribosomal-protein-alanine $\mathrm{N}$-acetyltransferase & 2.254871 & 1.463555 & -5.13538 & 7.73098 & $7.73 \mathrm{E}-05$ & 0.01723 & 0.854178 \\
\hline BUE60_24615 & threonine ammonia-lyase, biosynthetic & -2.31336 & -7.75066 & -2.51696 & 7.85215 & $8.26 \mathrm{E}-05$ & 0.017737 & 0.580708 \\
\hline BUE60_14740 & hypothetical protein & -6.33963 & -6.33963 & 0.83639 & 7.541523 & $8.97 \mathrm{E}-05$ & 0.018564 & 0.670119 \\
\hline BUE60_19565 & hypothetical protein & 1.419291 & 2.063655 & 2.243516 & 10.73711 & 0.000108 & 0.021543 & 0.754757 \\
\hline BUE60_17855 & hypothetical protein & 1.644416 & 0.041077 & 0.333665 & 10.61235 & 0.000112 & 0.02158 & 0.934538 \\
\hline BUE60_15390 & gamma carbonic anhydrase family protein & 0.672182 & -0.73084 & -6.19487 & 7.496001 & 0.000115 & 0.02158 & 0.722079 \\
\hline BUE60_02340 & transposase & -5.51749 & 3.725977 & 1.970766 & 8.817886 & 0.000128 & 0.023196 & 0.714283 \\
\hline BUE60_12815 & 2-methylcitrate synthase & -3.05674 & -7.53602 & -3.3801 & 7.531794 & 0.000132 & 0.023209 & 0.872486 \\
\hline BUE60_18535 & ribosomal subunit interface protein & 1.422023 & -0.98943 & 0.057456 & 10.76842 & 0.000151 & 0.025747 & 0.757798 \\
\hline BUE60_19430 & hypothetical protein & 1.211633 & -5.7711 & -5.7711 & 7.283092 & 0.000158 & 0.0261 & 0.73941 \\
\hline BUE60_13595 & hypothetical protein & 1.636492 & -5.54256 & -5.54256 & 7.34782 & 0.000186 & 0.027557 & 0.412538 \\
\hline BUE60_21160 & hypothetical protein & 0.130148 & -6.04703 & -6.04703 & 6.997812 & 0.00019 & 0.027557 & 0.777151 \\
\hline BUE60_19345 & glutathione S-transferase & 0 & 6.553643 & 7.982156 & 7.93946 & 0.000185 & 0.027557 & 0.497624 \\
\hline BUE60_15180 & hypothetical protein & -0.64369 & -6.95686 & -6.95686 & 7.415176 & 0.000178 & 0.027557 & 0.528899 \\
\hline BUE60_07695 & Fis family transcriptional regulator & -6.07158 & 0.083934 & -6.07158 & 6.817511 & 0.000184 & 0.027557 & 0.867404 \\
\hline BUE60_24965 & hypothetical protein & 1.091995 & -5.7761 & -5.7761 & 7.223623 & 0.000198 & 0.027965 & 0.76029 \\
\hline BUE60_21340 & hypothetical protein & 0.489961 & -0.87607 & -6.23156 & 7.435516 & 0.000214 & 0.029594 & 0.678285 \\
\hline BUE60_01650 & thiosulfate sulfurtransferase & -6.07151 & 0.083998 & -6.07151 & 6.817511 & 0.000234 & 0.031502 & 0.867404 \\
\hline BUE60_10700 & molecular chaperone DnaK & 0 & 6.590735 & 7.732228 & 7.78859 & 0.000254 & 0.033474 & 0.499649 \\
\hline BUE60_27730 & glycoside hydrolase 68 family protein & 1.990119 & 1.550896 & 1.567534 & 10.9663 & 0.000266 & 0.034293 & 0.908225 \\
\hline BUE60_02230 & prevent-host-death protein & 0.759926 & -5.94885 & -5.94885 & 7.190749 & 0.000284 & 0.035773 & 0.772524 \\
\hline BUE60_17400 & transposase & -6.7498 & -0.97421 & -6.7498 & 7.043704 & 0.0004 & 0.049323 & 0.710718 \\
\hline BUE60_09700 & 30S ribosomal protein $\mathrm{S} 3$ & -0.25804 & -0.86626 & -1.83476 & 10.5992 & 0.000433 & 0.052335 & 0.756287 \\
\hline BUE60_25785 & chaperonin GroL & 0.57601 & -1.49145 & -0.64014 & 10.64873 & 0.000447 & 0.052893 & 0.806498 \\
\hline BUE60_23685 & type III chaperone protein $\mathrm{ShcN}$ & 0.791859 & 2.274048 & 1.261047 & 10.05967 & 0.0005 & 0.057302 & 0.729401 \\
\hline BUE60_06660 & hypothetical protein & 0.308284 & 0.295896 & -5.96605 & 7.341313 & 0.000504 & 0.057302 & 0.772319 \\
\hline BUE60_12330 & cysteine hydrolase & 2.283692 & 2.685102 & -4.08027 & 7.224962 & 0.000553 & 0.060751 & 0.598509 \\
\hline
\end{tabular}




\begin{tabular}{|c|c|c|c|c|c|c|c|c|}
\hline BUE60_18905 & HslU--HslV peptidase proteolytic subunit & 1.65815 & 0.192043 & 2.487488 & 9.847487 & 0.000566 & 0.060751 & 0.826576 \\
\hline BUE60_28885 & IS66 family transposase & 0.407687 & -6.25623 & -6.25623 & 7.261808 & 0.000566 & 0.060751 & 0.430101 \\
\hline BUE60_26610 & transposase & 0 & 7.163183 & 8.603967 & 8.477509 & 0.000609 & 0.064132 & 0.24148 \\
\hline BUE60_19335 & hypothetical protein & 3.39819 & 1.071081 & -4.22353 & 7.607979 & 0.000658 & 0.065776 & 0.780608 \\
\hline BUE60_17470 & $\begin{array}{c}\text { 1-(5-phosphoribosyl)-5-((5-phosphoribosylamino) } \\
\text { methylideneamino)imidazole-4- } \\
\text { carboxamide isomerase }\end{array}$ & 0.1607 & -6.29092 & -6.29092 & 7.188882 & 0.000652 & 0.065776 & 0.404107 \\
\hline BUE60_12825 & GntR family transcriptional regulator & -3.71429 & -7.56884 & -3.23523 & 7.521741 & 0.000643 & 0.065776 & 0.622523 \\
\hline BUE60_29200 & hypothetical protein & -2.68519 & -7.0603 & -7.0603 & 7.110864 & 0.000695 & 0.068254 & 0.751303 \\
\hline BUE60_07150 & IS3 family transposase & 3.570854 & -3.93558 & -3.93558 & 7.380453 & 0.000707 & 0.068298 & 0.528357 \\
\hline BUE60_21075 & phna protein alkylphosphonate uptake & 0.018146 & -1.62145 & -6.47975 & 7.385461 & 0.000726 & 0.068957 & 0.759865 \\
\hline BUE60_27745 & hypothetical protein & 1.89857 & 0.396512 & -6.92905 & 8.922955 & 0.000745 & 0.069619 & 0.644543 \\
\hline BUE60_21475 & $\mathrm{ABC}$ transporter substrate-binding protein & 2.601267 & 0.065625 & 0.341459 & 8.703373 & 0.000796 & 0.073259 & 0.828218 \\
\hline BUE60_28550 & hypothetical protein & 6.282644 & 8.43938 & 0 & 7.912608 & 0.000845 & 0.075941 & 0.40412 \\
\hline BUE60_15495 & hypothetical protein & 1.808798 & 2.130559 & 1.632545 & 9.785202 & 0.000852 & 0.075941 & 0.825144 \\
\hline BUE60_22845 & hypothetical protein & -6.87515 & 1.564223 & -6.87515 & 8.061091 & 0.000944 & 0.082881 & 0.365741 \\
\hline BUE60_02805 & D-hexose-6-phosphate mutarotase & -0.98576 & -3.05392 & -1.17007 & 9.230321 & 0.000979 & 0.084697 & 0.784073 \\
\hline BUE60_28540 & phospholipase & 0 & 7.511676 & 0 & 6.884314 & 0.001001 & 0.085306 & 0.45 \\
\hline BUE60_15770 & dipeptide $\mathrm{ABC}$ transporter permease $\mathrm{DppC}$ & -3.81395 & 3.113897 & -3.81395 & 6.646059 & 0.001023 & 0.085963 & 0.866672 \\
\hline BUE60_25850 & IS630 family transposase & -5.25668 & 2.859024 & -5.25668 & 7.527171 & 0.001048 & 0.08674 & 0.421919 \\
\hline BUE60_23415 & hypothetical protein & -6.49249 & -0.63362 & -6.49249 & 6.929545 & 0.001133 & 0.092485 & 0.629163 \\
\hline BUE60_06270 & efflux transporter periplasmic adaptor subunit & -1.16271 & -0.59189 & -6.46943 & 7.196219 & 0.00117 & 0.092932 & 0.674268 \\
\hline BUE60_02790 & sugar $\mathrm{ABC}$ transporter permease & -1.60463 & -1.04277 & -1.66657 & 10.4278 & 0.001167 & 0.092932 & 0.729736 \\
\hline BUE60_11475 & $\begin{array}{l}\mathrm{Cd}(\mathrm{II}) / \mathrm{Pb}(\mathrm{II}) \text {-responsive transcriptional } \\
\text { regulator }\end{array}$ & 1.789462 & 1.420796 & -4.80667 & 7.242217 & 0.001252 & 0.098092 & 0.730896 \\
\hline BUE60_08690 & flagellar biosynthetic protein FliO & 1.326382 & -5.15132 & -5.15132 & 6.890662 & 0.001273 & 0.098371 & 0.849329 \\
\hline BUE60_28090 & transposase & 0 & 7.452437 & 0 & 6.844453 & 0.001307 & 0.098371 & 0.45 \\
\hline BUE60_19630 & hypothetical protein & -2.56629 & -6.85827 & -6.85827 & 6.97748 & 0.001307 & 0.098371 & 0.925232 \\
\hline BUE60_01880 & phage tail protein & 6.780487 & 5.307834 & 6.57077 & 7.564627 & 0.001339 & 0.099517 & 0.635214 \\
\hline
\end{tabular}

$3{ }^{\mathrm{a}}$ Gene expression ratio in $27^{\circ} \mathrm{C}-\mathrm{HSC}$ medium against $27^{\circ} \mathrm{C}-\mathrm{HS}$ medium. 
$4{ }^{\mathrm{b}} \mathrm{Gene}$ expression ratio in $18^{\circ} \mathrm{C}$-HS medium against $27^{\circ} \mathrm{C}-\mathrm{HS}$ medium.

$5{ }^{\mathrm{c}}$ Gene expression ratio in $18^{\circ} \mathrm{C}$-HSC medium against $27^{\circ} \mathrm{C}-\mathrm{HS}$ medium. 


\section{Table 3 (on next page)}

Expression of $c f a 1$ and $c m a D$ of Psa6 and Psg by RT-qPCR analysis 
1 Table 3. Expression of $c f a l$ and $c m a D$ of Psa6 and Psg by RT-qPCR analysis

\begin{tabular}{|ccccc|ccccc|}
\hline Gene & Condition & $0 \mathrm{~h}$ & $3 \mathrm{~h}$ & $6 \mathrm{~h}$ & Gene & Condition & $0 \mathrm{~h}$ & $3 \mathrm{~h}$ & $6 \mathrm{~h}$ \\
\hline \multirow{4}{*}{ Psa6 } & $27 \mathrm{HS}$ & 0.00 & $\mathbf{1 . 8 7}$ & $\mathbf{2 . 8 3}$ & & $27 \mathrm{HS}$ & 0.00 & 0.08 & $\mathbf{3 . 8 4}$ \\
$c f a l$ & $27 \mathrm{HSC}$ & 0.00 & 0.79 & $\mathbf{2 . 4 3}$ & Psg & $27 \mathrm{HSC}$ & 0.00 & 0.27 & $\mathbf{3 . 7 6}$ \\
& $27 \mathrm{LB}$ & 0.00 & -3.90 & -4.55 & $c f a l$ & $27 \mathrm{LB}$ & 0.00 & 0.58 & $\mathbf{3 . 7 3}$ \\
& $27 h r p$ & 0.00 & -3.46 & -3.88 & & $27 \mathrm{hrp}$ & 0.00 & 0.29 & $\mathbf{3 . 5 5}$ \\
\hline & $27 \mathrm{HS}$ & 0.00 & $\mathbf{3 . 7 2}$ & $\mathbf{5 . 7 3}$ & & $27 \mathrm{HS}$ & 0.00 & 0.18 & -0.29 \\
Psa6 & $27 \mathrm{HSC}$ & 0.00 & $\mathbf{1 . 3 2}$ & $\mathbf{5 . 4 1}$ & Psg & $27 \mathrm{HSC}$ & 0.00 & 0.57 & 0.06 \\
cmaD & $27 \mathrm{LB}$ & 0.00 & 0.89 & $\mathbf{1 . 3 0}$ & $c m a D$ & $27 \mathrm{LB}$ & 0.00 & 0.86 & -0.58 \\
& $27 h r p$ & 0.00 & 0.78 & $\mathbf{1 . 4 0}$ & & $27 h r p$ & 0.00 & 0.57 & -0.56 \\
\hline
\end{tabular}

2 The expression level $\left(\log _{2}\right)$ is indicated as a ratio relatively against $0 \mathrm{~h}$ of each culture condition.

3 Bold letters indicate that expression is induced $\left(\log _{2}>1.0\right)$, and blue letters indicate that

4 expression is suppressed $\left(\log _{2}<-1.0\right)$.

5 


\section{Table 4 (on next page)}

Expression of argK and argD of Psa6 and Psa1 by RT-qPCR analysis 
1 Table 4. Expression of $\arg K$ and $\arg D$ of Psa6 and Psa1 by RT-qPCR analysis

\begin{tabular}{|c|c|c|c|c|c|c|c|c|c|}
\hline Gene & Sample & $\mathrm{Oh}$ & $3 \mathrm{~h}$ & $6 \mathrm{~h}$ & Gene & Sample & Oh & $3 \mathrm{~h}$ & $6 \mathrm{~h}$ \\
\hline & $27 \mathrm{HS}$ & 0.00 & 4.81 & 3.13 & \multirow{4}{*}{$\begin{array}{l}\text { Psa1 } \\
\arg K\end{array}$} & $27 \mathrm{HS}$ & 0.00 & 0.28 & 1.78 \\
\hline Psa6 & $27 \mathrm{HSC}$ & 0.00 & 4.93 & 2.66 & & $27 \mathrm{HSC}$ & 0.00 & -0.24 & 0.89 \\
\hline \multirow[t]{2}{*}{$\arg K$} & $27 \mathrm{LB}$ & 0.00 & 1.85 & 3.78 & & $27 \mathrm{LB}$ & 0.00 & 2.09 & 0.85 \\
\hline & $27 h r p$ & 0.00 & 1.31 & 2.92 & & $27 h r p$ & 0.00 & 1.97 & 0.95 \\
\hline \multirow{4}{*}{$\begin{array}{l}\text { Psa6 } \\
\arg D\end{array}$} & $27 \mathrm{HS}$ & 0.00 & 0.89 & 2.74 & \multirow{4}{*}{$\begin{array}{l}\text { Psal } \\
\arg D\end{array}$} & $27 \mathrm{HS}$ & 0.00 & -0.30 & 0.12 \\
\hline & $27 \mathrm{HSC}$ & 0.00 & 0.91 & 2.04 & & 27HSC & 0.00 & -0.71 & -0.35 \\
\hline & $27 \mathrm{LB}$ & 0.00 & -5.12 & -5.20 & & $27 \mathrm{LB}$ & 0.00 & -0.01 & 0.30 \\
\hline & $27 \mathrm{hrp}$ & 0.00 & -5.39 & -5.29 & & $27 \mathrm{hrp}$ & 0.00 & -0.01 & 0.03 \\
\hline
\end{tabular}

2 The expression level $\left(\log _{2}\right)$ is indicated as a ratio relatively against $0 \mathrm{~h}$ of each culture condition.

3 Bold letters indicate that expression is induced $\left(\log _{2}>1.0\right)$, and blue letters indicate that

4 expression is suppressed $\left(\log _{2}<-1.0\right)$.

5 
Figure 1

Comparison of expression trends in the RNA-seq and RT-qPCR analyses.

The expression levels of the virulence genes in RNA-Seq were plotted on the vertical axis and that in RT-qPCR were plotted on the horizontal axis. Most of the plots were concentrated in the first and third quadrants, while some were concentrated in the second and fourth quadrants. The yellow wavy line indicates a linear approximation, and $R^{2}$ value (about 0.6) was obtained.

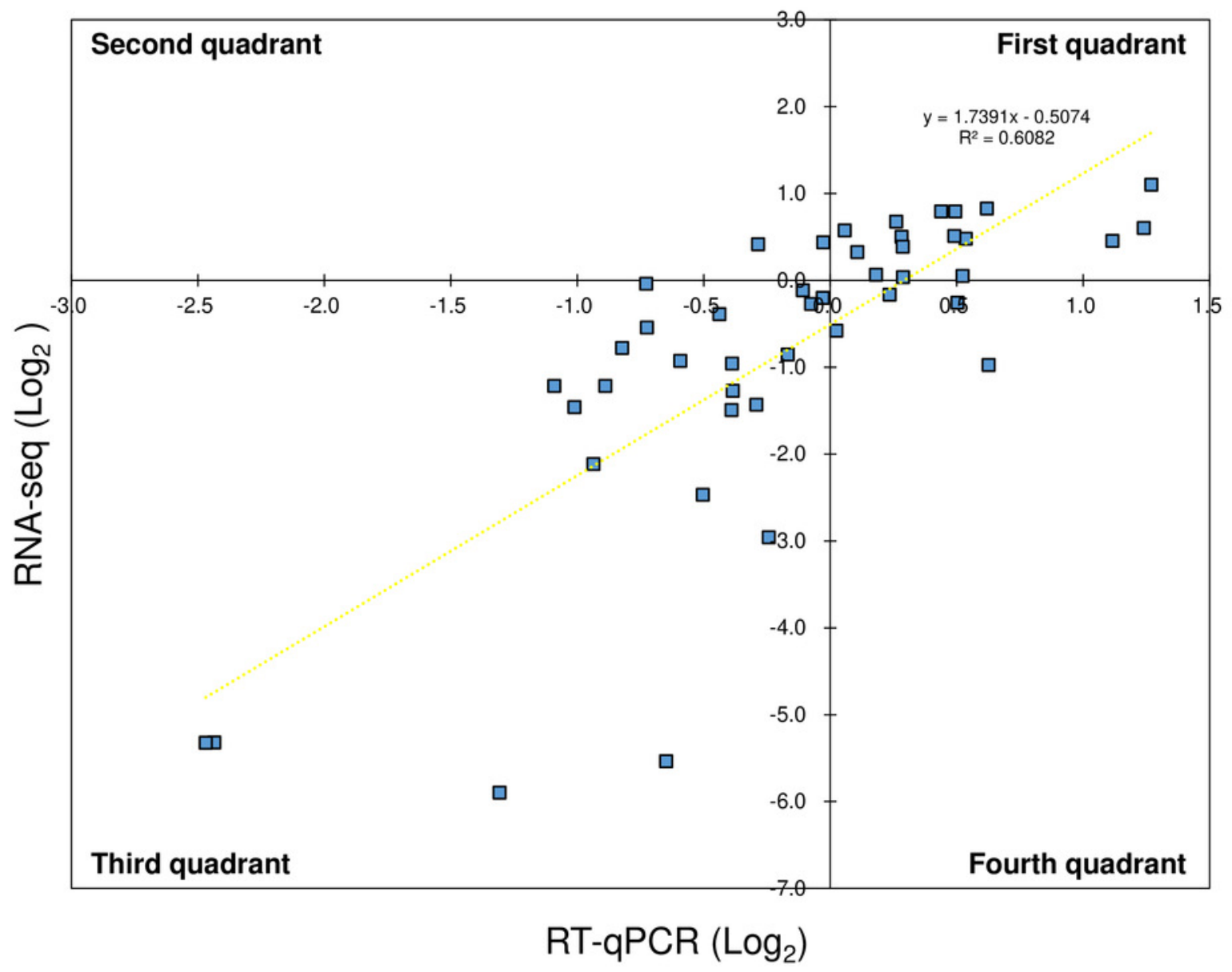




\section{Figure 2}

Heat map constructed from the expression level of virulence genes of Psa6 under each culture condition.

The results of RT-qPCR analysis of Psa6 were clustered using the unweighted pair group method with arithmetic mean (UPGMA). A, Heat map of expression levels of virulence genes under each culture condition. B, Reconstructed heat map excluding the conditions of the hrpinducing medium. Gene names highlighted in blue are phaseolotoxin synthesis genes, and gene names highlighted in yellow are coronatine synthesis genes. Remaining genes are type III effectors. In heat maps, induced genes are indicated as yellow boxes and suppressed genes are indicated as blue boxes.

A

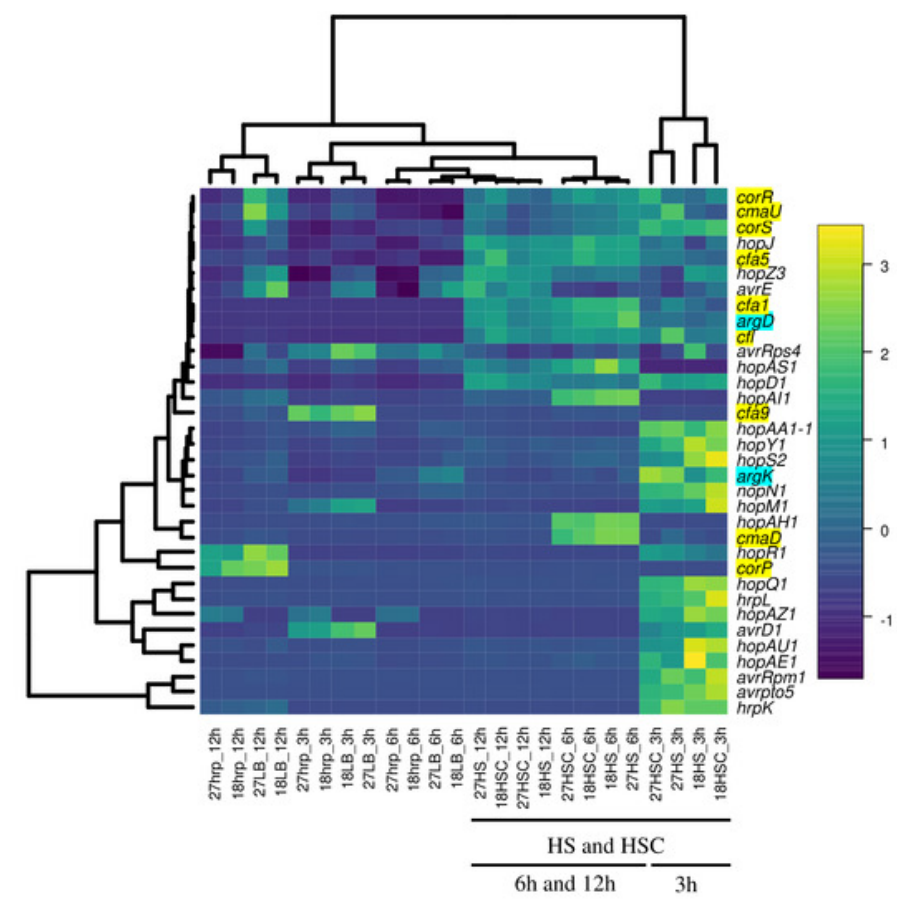

B

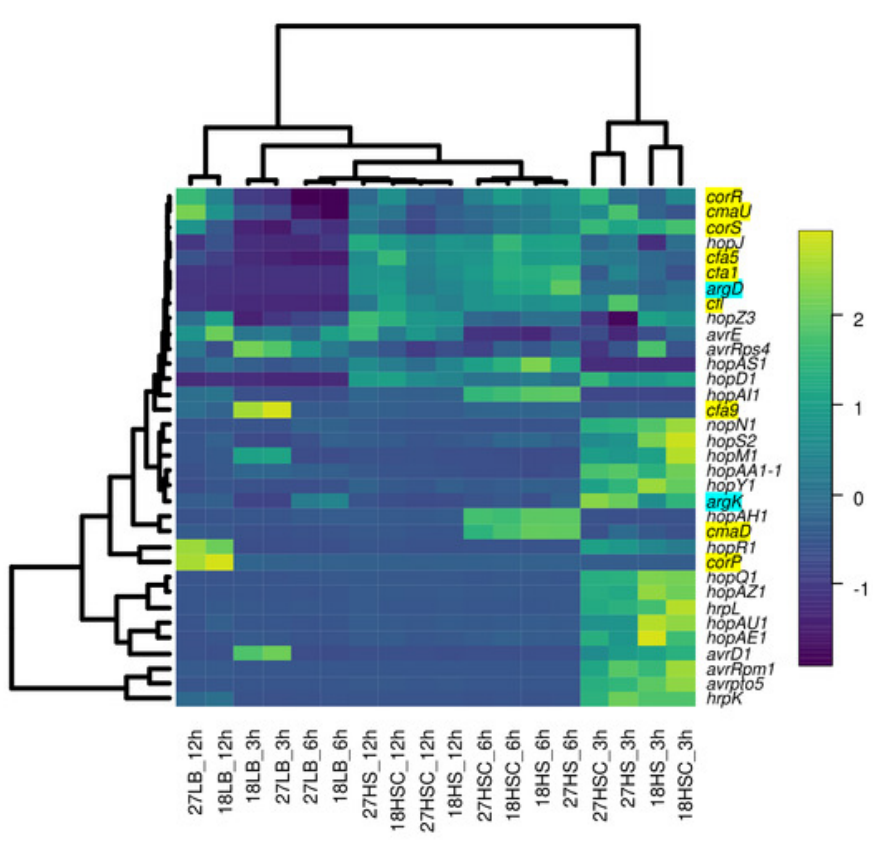




\section{Figure 3}

Heat map constructed from the expression levels of virulence genes of Psa6, Psa1, Psa3, and Psg under each culture condition.

The results of RT-qPCR analysis of Psa6, Psa1, Psa3, and Psg were clustered using the unweighted pair group method with arithmetic mean (UPGMA). A, Heat map of expression levels of virulence genes under each culture condition. B, Reconstructed heat map excluding the results of both Psa6 and Psg. In heat maps, induced genes are indicated as yellow boxes and suppressed genes are indicated as blue boxes.

A

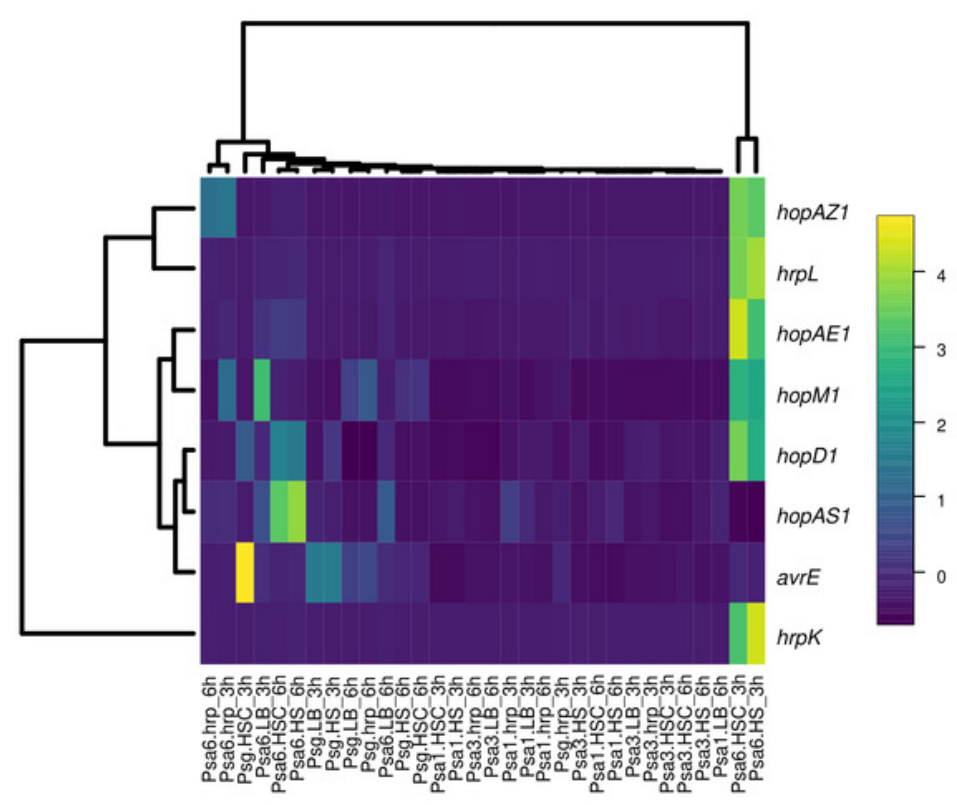

B

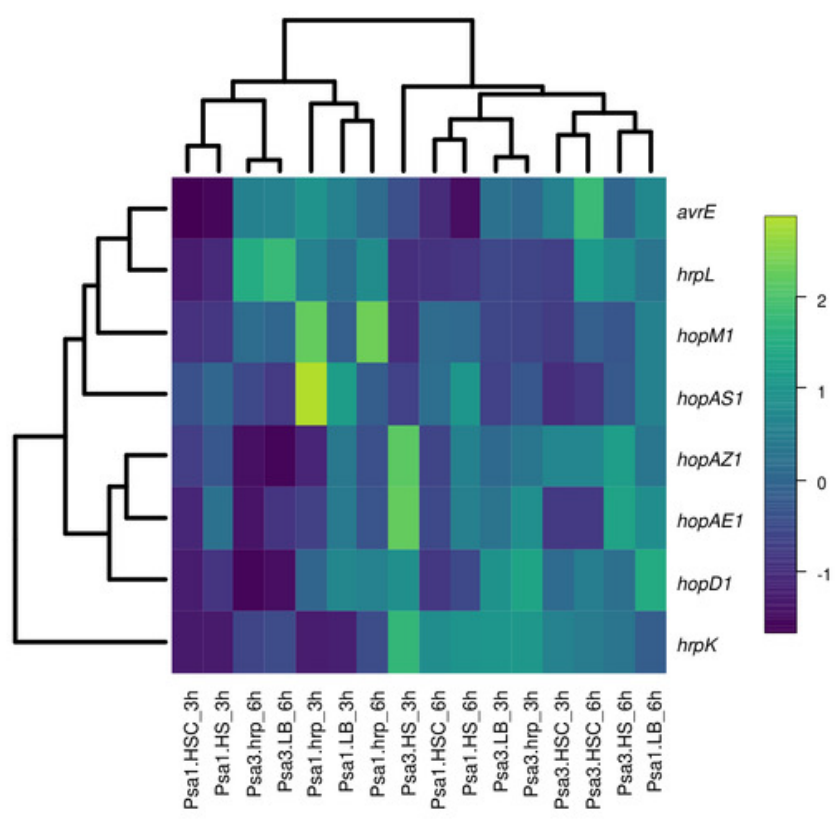




\section{Figure 4}

Schematic diagram of the expression pattern of Psa6 virulence genes in different media.

The expression of virulence genes (type III effector genes and phytotoxin synthesis genes) of

Psa6 was induced in the coronatine-producing media, and the expression behavior had two patterns: early-inducible and late-inducible. These genes were suppressed or constant in LB medium and the $h r p$-inducing medium.
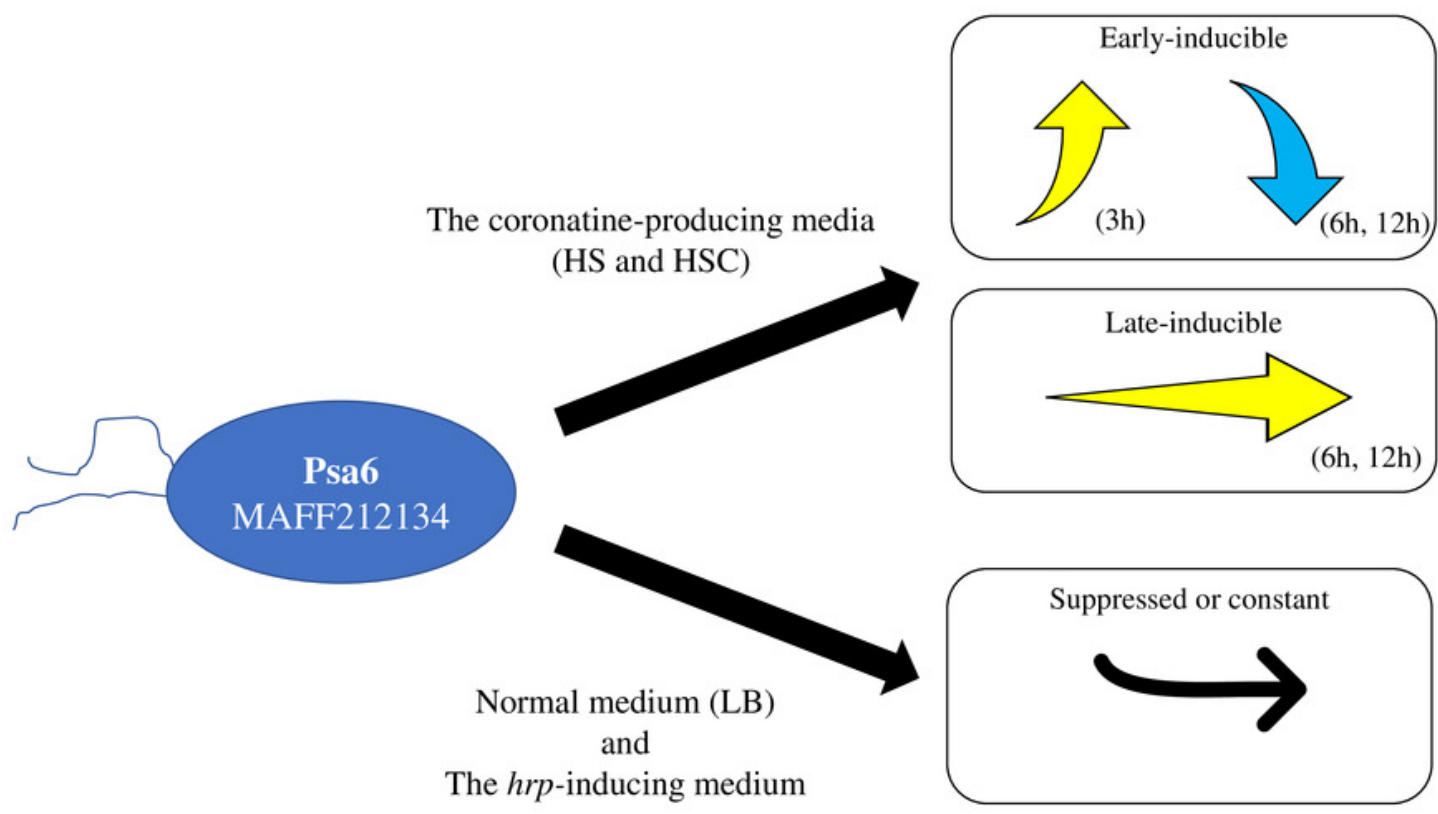

Effectors: $h r p L, a v r D I$, avrpto5, avrRpml, hорAA1-1, hopAEl, hopAU1, hopAZl, hopMI, hopNI, hopQI, hopRI, hopS2, hopY1, hrpK Phaseolotoxin: $\arg K$

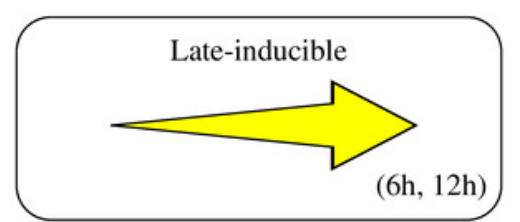

Effectors: avrE1, avrRps4, hopAHI, hopAI1, hopAS1, hopD1, hopJ, hopZ3,

Coronatine: $c f l, c f a l$, cfa5, cfa9, cmaD, cmaU, corP, $\operatorname{cor} R$, cor $S$

Phaseolotoxin: $\arg D$

Suppressed or constant

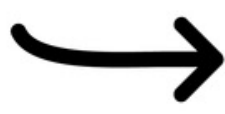

The hrp-inducing medium 